\title{
MONITORING OF PARASITIC DISEASES OF DOGS
}

\author{
Bogdan Morozov $\bowtie$ \\ Department of of Veterinary Examination, Microbiology, Zoohygiene \\ and Safety and Quality of Livestock Products ${ }^{1}$ \\ MorozovBS@meta.ua \\ Andrii Berezovskyi \\ Department of of Veterinary Examination, Microbiology, Zoohygiene \\ and Safety and Quality of Livestock Products ${ }^{1}$ \\ ${ }^{1}$ Sumy National Agrarian University \\ 160 Herasyma Kondratieva str., Sumy, Ukraine, 40021
}

$\triangle$ Corresponding author

\begin{abstract}
During the study, dogs were diagnosed with the following helminthic diseases: toxocariasis, echinococcosis, uncinariosis, trichuriasis, capillariosis, dipilidiosis, which took the form of mono and mixed invasions.

The aim of this study was to identify the intensity of helminth infestation of dogs of different ages and methods of keeping.

Materials and methods. Experimental studies were conducted during 2018-2020 on the basis of the laboratory «Innovative technologies and safety and quality of livestock products» and «Veterinary Pharmacy» of the Department of Veterinary Examination, Microbiology, Zoohygiene and Safety and Quality of Livestock Products; epizootology and parasitology of the Faculty of Veterinary Medicine of Sumy National Agrarian University.

In cities and villages, faecal samples were taken from dogs, taking into account the method of keeping (tethered or untethered) and their use (office, hunting, decorative, etc.), which were placed in airtight containers, labeled samples and sent to the laboratory for the research.

The object of clinical and laboratory research were dogs aged one to seven years, admitted to veterinary clinics in the period from 2018 to 2020, with suspected helminthic diseases. Testing of dogs was performed by collecting medical history and clinical examination.

Results. According to the results of the research, it was established that among helminthic diseases during 2018-2020 the following diseases were registered: toxocariasis, cestodes, uncinariosis of dogs. Among the blood-parasitic diseases for the period 2018-2020 were diagnosed with heartworm disease, babesiosis of dogs.

Among ectoparathyroidism, the laboratory diagnosed demodectic mange, otodectosis, canine sarcoptosis, and carnivorous syphonepterosis. A total of 513 surveys were conducted in 2018, of which 80 were positive; for 2019-509, of which positive - 58; for $2020-488$, of which 62 are positive.

Conclusions. Intestinal helminthiasis has been found to account for the lowest proportion (11\%) of carnivorous parasitic diseases compared to blood parasitic diseases (19\%) and ectoparasitosis (70 \%), but they are of great interest for study because of their significant epidemiological significance and may be the cause of disease in humans.

It has been proven that helminthic diseases of dogs run as mixed invasion, and a minority of cases $31.7 \%$ of cases run as mono invasion. Of the total number of patients with helminthic diseases, $73.4 \%$ of the total number of animals were accompanied by other diseases of infectious and non-infectious ethology.
\end{abstract}

Keywords: parasitology, intestinal helminthiasis, mono invasion, mixed invasion, dogs.

DOI: $10.21303 / 2504-5679.2021 .001987$

\section{Introduction}

Literature data indicate that parasitic diseases of dogs are widespread both abroad and in Ukraine, both among service and hunting dogs kept in nurseries, and among ornamental, domestic animals $[1,2]$. It should be noted that parasitic diseases of dogs caused by helminths as a pathology occupy a significant place among other diseases. Helminths, along with the threat to animal health, have social significance, because millions of domestic and stray animals, especially in large cities, being in close proximity to humans and being carriers of zoonoses [3], pose a threat to their health not only owners but also other people.

Dogs are closely related to humans, providing communication, security and a source of dietary protein. However, dogs are also potential carriers of zoonotic agents. Thus, dogs pose a risk 
to public health, and a good understanding of canine diseases is important for planning and implementing control measures.

The study of the main helminthiasis of dogs, issues of therapy and prevention of the most common helminthiasis in some cities is of some scientific and practical interest [4].

Carnivorous animals infected with individual helminths spread them among farm animals and humans, causing serious diseases [5]. Despite the declining trend of intestinal parasites in dogs in recent decades, they still pose a serious epidemiological problem.

Analysis of the literature showed that parasitic diseases of dogs have a wide range of prevalence [6]. In urban conditions, the contact of dogs and cats with humans becomes closer, which causes the danger of mass infection of people with helminthiasis. Contamination of the environment with exogenous forms of helminths contributes to the spread of helminthiasis in animals and humans.

Dogs are the most popular pets in the world, but they often suffer from helminthiasis, which can pose a threat to human health, especially children, the elderly and people with immune disorders [7]. Helminthic diseases of dogs pose a serious epidemiological danger to humans. Helminthiasis of dogs is common in both urban and rural areas. The most common helminthiases are: toxocariasis, hookworm, dipilidiosis, uncinariosis, etc. Puppies under 6 months of age are most prone to infection [8]. In some cases, death is possible. For a long time, some living organisms in the process of life have adapted to the parasitic way of life, when all the substances necessary for their development, they receive from another organism (host). About 1.5 million (according to some scientists -2 million) species of living organisms of animal origin have been registered on the globe. Of these, almost 90,000 species (6\%) lead a parasitic lifestyle [9].

Zoonoses are those diseases that are transmitted between human and animal populations. In this regard, dogs and cats are considered a public health problem because they can be carriers of various pathogens such as zoonotic helminths, including Toxocara species [10]. Toxocara canis can cause diarrhoea, growth retardation and death if present in large quantities in puppies. Ancylostoma spp. are one of the most pathogenic helminths in dogs, especially in puppies. These nematodes are hematophagous and can cause anaemia and death if present in large numbers.

Zoonotic helminths of dogs pose a danger to public health due to fecal contamination of the environment. Infection of dogs and humans with zoonotic helminths can occur as a result of swallowing infectious eggs and entering the body or penetrating through the skin of infectious larvae. Human infection with Toxocara spp. usually asymptomatic, but some people develop a migrating visceral larva and ocular toxocariasis. Ancylostoma spp. are etiological pathogens of cutaneous migratory Ancylostoma spp. Larva has also been associated with eosinophilic enteritis in humans [11]. Therefore, it is important to understand the epidemiology of helminthiasis in dogs to improve animal health and prevent the spread of zoonotic pathogens among humans.

In both infectious and invasive diseases, the mechanism of pathogen transmission is the least studied, and especially its quantitative aspect. The study of the sources and ways of infecting dogs with major helminthiasis deserves great attention, as these data are used in the organization of the fight against invasion.

To successfully develop measures to combat and prevent invasive diseases, it is important to know the migration routes and locations of zooparasites in the host.

The aim of this study was to determine the features of the spread of helminthic pathogens in dogs in the Sumy region and to develop measures for the treatment and prevention of these diseases.

\section{Materials and methods}

The research was performed on the basis of the laboratory «Innovative technologies and safety and quality of livestock products» and «Veterinary Pharmacy» of the Department of Veterinary Examination, Microbiology, Zoohygiene and Safety and Quality of Livestock Products; epizootology and parasitology of the Faculty of Veterinary Medicine of Sumy National Agrarian University.

In the cities and villages of the North-Eastern region of Ukraine, faecal samples were taken from dogs, taking into account the method of keeping dogs (tethered or untethered) and their use (office, hunting, decorative, etc.), which were placed in airtight containers, labelled samples and sent to the laboratory for the research. 
The object of clinical and laboratory studies were dogs aged from one month to seven years, with suspected helminthic diseases in the period from 2018 to 2020. The study was performed on 412 animals. Testing of dogs was performed by collecting medical history and clinical examination.

All animal studies were performed in accordance with Directive 2010/63/EU as amended by Regulation (EC) 2019/1010 and approved by the conclusion of the Commission on Ethics and Bioethics of the Faculty of Veterinary Medicine of Sumy National Agrarian University, protocol No. 5 from 12.04.2021.

The presence of helminth eggs in the feces was studied by the Fulleborn method. The study was performed by flotation using a solution of ammonium nitrate, which was prepared by dissolving $1.5 \mathrm{~kg}$ of nitrate in 1 liter of water (solution density - 1.3) [12].

In the laboratory, the samples were placed in a container with distilled water and after thorough mixing, filtered through layers of gauze, then the contents were transferred to centrifuge tubes. Centrifugation was performed at 3000-3500 rpm. $30 \mathrm{~min}$ after centrifugation, the supernatant was drained, and the same volume of distilled water was added to the precipitate, the contents were stirred, and centrifuged a second time for 20 minutes. After centrifugation, the supernatant was drained, and the precipitate was examined by microscopy for the presence of helminth eggs [13].

Studies of the species of helminth eggs were performed on morphological (shape, size, color, number of shells) and biological (embryo development) [14].

Statistical processing of the results was performed using Microsoft Excel for Windows 2010. Data were calculated using the Fisher-Student method, taking into account statistical errors and the probability of the indicators that were compared. Considered probable indicators with a level of more than $95 \%(p<0.05)$.

\section{Results}

At the first stage of our research, an analysis of statistical reporting on dog diseases in the city's veterinary clinics was conducted. It was found that among the helminthic diseases during 2018-2020 the following diseases were registered: toxocariasis, cestodes, uncinariosis of dogs.

Among the blood-parasitic diseases were diagnosed with heartworm disease and babesiosis in dogs.

Among ectoparasitosis, the laboratory diagnosed demodectic mange, otodectosis, canine sarcoptosis, and carnivorous syphonepterosis. Ectoparasitosis of carnivorous animals in the laboratory was diagnosed in most cases.

For diseases such as carnivorous babesiosis, carnivorous eimeriosis, the laboratory received material, but the causative agents of these diseases were not detected. Data for these studies are shown in Table 1.

Table 1

Results of the research on parasitic diseases of carnivores for 2018-2020

\begin{tabular}{|c|c|c|c|c|c|c|c|c|c|}
\hline \multirow[b]{2}{*}{ The name of the disease } & \multicolumn{3}{|c|}{2018} & \multicolumn{3}{|c|}{2019} & \multicolumn{3}{|c|}{2020} \\
\hline & $\begin{array}{c}\text { Number } \\
\text { of mate- } \\
\text { rials }\end{array}$ & $\begin{array}{c}\text { Number } \\
\text { of positive } \\
\text { results }\end{array}$ & $\begin{array}{c}\% \text { of } \\
\text { positive } \\
\text { results }\end{array}$ & $\begin{array}{c}\text { Number } \\
\text { of mate- } \\
\text { rials }\end{array}$ & $\begin{array}{c}\text { Number } \\
\text { of positive } \\
\text { results }\end{array}$ & $\begin{array}{c}\% \text { of } \\
\text { positive } \\
\text { results }\end{array}$ & $\begin{array}{c}\text { Number } \\
\text { of mate- } \\
\text { rials }\end{array}$ & $\begin{array}{c}\text { Number } \\
\text { of positive } \\
\text { results }\end{array}$ & $\begin{array}{c}\% \% \text { of } \\
\text { positive } \\
\text { results }\end{array}$ \\
\hline Heartworm disease in dogs & 63 & 8 & 12.7 & 79 & 9 & 11.4 & 71 & 11 & 15.5 \\
\hline Toxocariasis of dogs & 42 & 5 & 11.9 & 35 & 4 & 11.4 & 39 & 3 & 7.7 \\
\hline Cestodes of dogs & 10 & 2 & 20.0 & 12 & 1 & 8.3 & 8 & 1 & 12.5 \\
\hline Babesiosis of carnivores & 3 & 0 & 0.0 & 4 & 0 & 0.0 & 2 & 0 & 0.0 \\
\hline Carnivorous eimeriosis & 21 & 0 & 0.0 & 22 & 0 & 0.0 & 24 & 0 & 0.0 \\
\hline Demodicosis of dogs & 68 & 20 & 29.4 & 63 & 14 & 22.2 & 60 & 16 & 26.7 \\
\hline Otodectosis of dogs & 68 & 8 & 11.8 & 62 & 3 & 4.8 & 63 & 5 & 7.9 \\
\hline Sarcoptosis of dogs & 21 & 8 & 38.1 & 30 & 4 & 13.3 & 20 & 3 & 15.0 \\
\hline Syphonepteroses of carnivores & 21 & 18 & 85.7 & 18 & 14 & 77.8 & 16 & 15 & 93.8 \\
\hline Uncinariosis of dogs & 12 & 3 & 25.0 & 14 & 4 & 28.6 & 12 & 2 & 16.7 \\
\hline
\end{tabular}


The ratio of positive research results obtained in the laboratory is shown in Fig. 1.

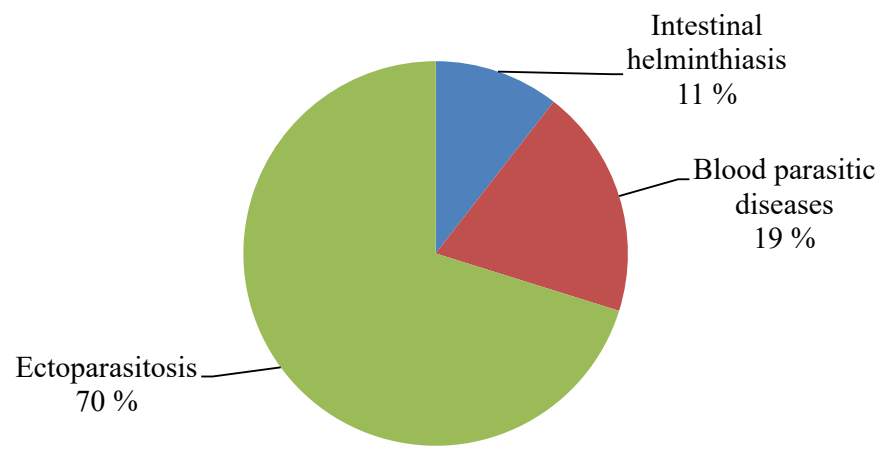

Fig. 1. The ratio of positive results for parasitic carnivorous diseases

It was found that $56.8 \%$ (49 of 85 samples) of dogs belonging to urban residents were infected with intestinal helminths. Helminthiasis was registered in the form of mono- and mixed invasions (Table 2).

Table 2

The spectrum of helminth fauna of dogs in urban areas, $n=10$

\begin{tabular}{|c|c|c|c|c|c|c|c|c|}
\hline \multirow[b]{2}{*}{ No. } & \multirow{2}{*}{$\begin{array}{l}\text { Conditions } \\
\text { of detention }\end{array}$} & \multicolumn{7}{|c|}{ Intensity of invasions, specimens/eggs } \\
\hline & & $\begin{array}{c}\text { Echinococcus } \\
\text { granulosus }\end{array}$ & $\begin{array}{l}\text { Toxocara } \\
\text { canis }\end{array}$ & $\begin{array}{c}\text { Toxascaris } \\
\text { leonine }\end{array}$ & $\begin{array}{l}\text { Capillaria } \\
\text { plica }\end{array}$ & $\begin{array}{l}\text { Trichuris } \\
\text { vulpis }\end{array}$ & $\begin{array}{c}\text { Uncinaria } \\
\text { stenocephala }\end{array}$ & $\begin{array}{c}\text { Dipylidium } \\
\text { caninum }\end{array}$ \\
\hline 1 & 2 & 3 & 4 & 5 & 6 & 7 & 8 & 9 \\
\hline 1 & Untethered & - & - & - & - & $3.3 \pm 0.3$ & $0.3 \pm 0.1$ & - \\
\hline 2 & Untethered & - & - & - & - & $2.9 \pm 0.6$ & - & - \\
\hline 3 & Untethered & - & $1.3 \pm 0.1$ & $5.1 \pm 0.2$ & - & $5.3 \pm 0.8$ & - & $3.2 \pm 0.5$ \\
\hline 4 & Untethered & - & - & - & $1.4 \pm 0.2$ & - & - & - \\
\hline 5 & Untethered & - & - & - & - & - & $22.7 \pm 2.9$ & - \\
\hline 6 & Untethered & - & - & $2.8 \pm 0.4$ & - & - & - & - \\
\hline 7 & Untethered & - & $1.1 \pm 0.1$ & - & $2.4 \pm 0.6$ & - & - & - \\
\hline 8 & Untethered & $2.3 \pm 0.2$ & - & - & - & - & - & - \\
\hline 9 & Untethered & - & $2.8 \pm 0.3$ & - & - & - & $2.3 \pm 0.2$ & - \\
\hline 10 & Untethered & - & - & $2.4 \pm 0.6$ & - & $3.8 \pm 0.2$ & - & - \\
\hline 11 & Untethered & $1.3 \pm 0.1$ & - & - & - & - & - & - \\
\hline 12 & Untethered & - & $24.3 \pm 3.6$ & - & - & - & - & - \\
\hline 13 & Untethered & - & - & - & $21.3 \pm 0.5$ & - & - & - \\
\hline 14 & Untethered & $2.6 \pm 0.4$ & $32.4 \pm 4.8$ & - & - & $7.4 \pm 1.0$ & - & - \\
\hline 15 & Untethered & - & - & - & - & $12.3 \pm 2.1$ & - & - \\
\hline 16 & Tethered & - & - & - & $1.8 \pm 0.2$ & - & - & $6.3 \pm 0.3$ \\
\hline 17 & Tethered & - & - & $3.6 \pm 0.3$ & - & - & - & - \\
\hline 18 & Tethered & - & $0.6 \pm 0.1$ & - & $9.8 \pm 1.1$ & $1.1 \pm 0.2$ & $21.3 \pm 1.5$ & - \\
\hline 19 & Tethered & - & - & $7.1 \pm 1.2$ & - & - & - & $0.9 \pm 0.1$ \\
\hline 20 & Tethered & - & $4.6 \pm 0.6$ & - & - & - & - & $5.3 \pm 1.1$ \\
\hline 21 & Tethered & - & $9.3 \pm 1.2$ & - & - & - & $10.3 \pm 1.6$ & $8.1 \pm 1.8$ \\
\hline 22 & Tethered & - & $2.6 \pm 0.4$ & - & - & - & $10.2 \pm 1.4$ & - \\
\hline 23 & Tethered & - & - & - & - & $21.3 \pm 2.6$ & - & - \\
\hline 24 & Tethered & - & - & $8.2 \pm 1.3$ & $1.2 \pm 0.2$ & - & - & $7.9 \pm 1.3$ \\
\hline 25 & Tethered & - & - & $1.5 \pm 0.2$ & - & - & - & - \\
\hline
\end{tabular}


Continuation of Table 2

\begin{tabular}{|c|c|c|c|c|c|c|c|c|}
\hline 1 & 2 & 3 & 4 & 5 & 6 & 7 & 8 & 9 \\
\hline 26 & Tethered & $0.9 \pm 0.1$ & - & - & - & - & - & - \\
\hline 27 & Tethered & - & $2.8 \pm 0.2$ & - & - & - & - & - \\
\hline 28 & Tethered & - & $6.5 \pm 0.9$ & - & - & - & - & - \\
\hline 29 & Tethered & - & - & 22.6 & - & - & $2.3 \pm 0.5$ & - \\
\hline 30 & Tethered & - & - & - & - & $14.3 \pm 2.8$ & - & - \\
\hline 31 & Tethered & - & - & $12.4 \pm 1.3$ & - & - & - & $6.3 \pm 0.5$ \\
\hline 32 & Tethered & - & $12.5 \pm 1.8$ & - & - & $25.7 \pm 2.3$ & - & - \\
\hline 33 & Tethered & $0.2 \pm 0.1$ & - & - & - & - & - & - \\
\hline 34 & Tethered & - & - & - & $2.3 \pm 0.3$ & - & - & - \\
\hline 35 & Tethered & - & $35.2 \pm 2.6$ & - & - & - & - & - \\
\hline 36 & Tethered & - & $12.8 \pm 1.3$ & - & - & - & - & - \\
\hline 37 & Tethered & - & - & - & - & - & - & $5.6 \pm 1.2$ \\
\hline 38 & Tethered & - & - & - & - & $14.3 \pm 2.6$ & - & - \\
\hline 39 & Tethered & - & - & - & $1.8 \pm 0.2$ & - & - & - \\
\hline 40 & Tethered & - & - & - & - & - & $7.8 \pm 2.3$ & $2.3 \pm 0.4$ \\
\hline 41 & Tethered & - & - & - & - & $16.2 \pm 1.8$ & - & - \\
\hline 42 & Tethered & - & - & - & $1.4 \pm 0.2$ & $7.9 \pm 1.4$ & - & - \\
\hline 43 & Tethered & - & $12.8 \pm 1.4$ & - & - & - & - & - \\
\hline 44 & Tethered & $0.6 \pm 0.1$ & - & - & - & - & - & - \\
\hline 45 & Tethered & - & - & - & $2.1 \pm 0.1$ & - & - & - \\
\hline 46 & Tethered & - & - & - & $2.5 \pm 0.3$ & - & - & - \\
\hline 47 & Tethered & - & - & - & - & - & $5.6 \pm 0.9$ & - \\
\hline 48 & Tethered & - & - & - & - & - & $7.4 \pm 0.8$ & - \\
\hline 49 & Tethered & - & $14.8 \pm 2.3$ & - & - & - & - & - \\
\hline \multicolumn{2}{|c|}{ Extensiveness of invasion, $\%$} & 7,1 & 18.8 & 10.6 & 12.9 & 15.3 & 11.8 & 10.6 \\
\hline
\end{tabular}

Subsequently, studies of the dynamics of intestinal helminthiasis of dogs depending on age. To do this, helminthic coproscopy studies of animals of different age groups: puppies up to 1 month, 2-4 months, 4-6 months, 6-12 months, 1-2 years, 3-4 years, 5 and older were done.

The results of the defeat of dogs by intestinal helminths are given in Table 3.

Table 3

Detection of helminths in dogs depending on the age of the animals

\begin{tabular}{lccccccc}
\hline \multirow{2}{*}{ Age of the animal } & \multicolumn{8}{c}{ Type of helminth } \\
\cline { 2 - 7 } & $\begin{array}{c}\text { Echinococcus } \\
\text { granulosus }\end{array}$ & $\begin{array}{c}\text { Toxocara } \\
\text { canis }\end{array}$ & $\begin{array}{c}\text { Toxascaris } \\
\text { leonine }\end{array}$ & $\begin{array}{c}\text { Capillaria } \\
\text { plica }\end{array}$ & $\begin{array}{c}\text { Trichuris } \\
\text { vulpis }\end{array}$ & $\begin{array}{c}\text { Uncinaria } \\
\text { stenocephala }\end{array}$ & $\begin{array}{c}\text { Dipylidium } \\
\text { caninum }\end{array}$ \\
\hline The total number of infected animals, \% & 10 & 31 & 22 & 23 & 25 & 23 & 28 \\
Including up to 1 month, \% & - & 15 & - & - & - & - & - \\
2-4 months, \% & - & 9 & - & 3 & - & - & - \\
4-6 months, \% & - & 4 & - & 4 & - & 8 & 10 \\
6-12 months, \% & - & 1 & 8 & 3 & 1 & 7 & 7 \\
1-2 yrs., \% & 3 & - & 6 & 5 & 2 & 6 & 6 \\
3-4 yrs., \% & 4 & - & 6 & 5 & 10 & 2 & 2 \\
5 yrs. and older, \% & 3 & - & 2 & 3 & 12 & - & 3
\end{tabular}

The causative agent of Toxocara canis affected animals aged 1 month to 1 year. Young animals aged 1 to 6 months were particularly susceptible to nematode infestation. The pathogen 
Trichuris vulpis was detected in adult animals aged 3 to 5 years. In puppies 4-6 months Dipylidium caninum was isolated in $10 \%$ of cases. With age, the disease lost intensity.

The influence of housing conditions (tethered/untethered) on the degree of intestinal helminthiasis infection was further analyzed. A total of $152 \mathrm{dogs}$ were sampled during the study period, of which helminth eggs were found in 84 (55.3\%). Of the total number of free-range animals, 43 were dogs, 29 of which were infected with helminths. There were 109 dogs on a leash, 55 of which were infected with helminths (Fig. 2).

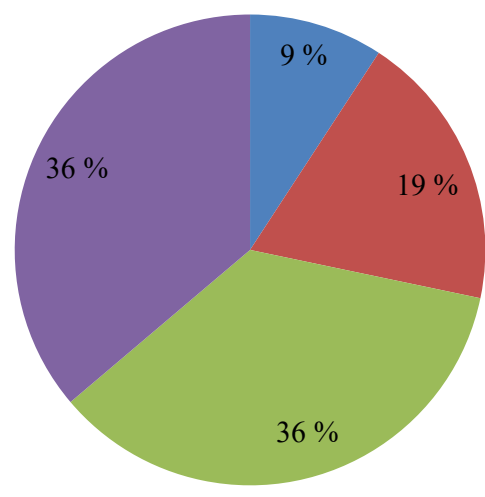

$$
\begin{aligned}
& \text { Dogs are kept untethered, unaffected } \\
& \square \text { Dogs are kept untethered, affected by helminthiasis } \\
& \square \text { Dogs are kept tethered, unaffected } \\
& \square \text { Dogs are kept tethered, affected by helminthiasis }
\end{aligned}
$$

Fig. 2. The influence of housing conditions on dogs affected by helminthiasis

As a result of data analysis, we could say that the number of helminth-infected animals was $10 \%$ higher when untethered than when tethered. When tethered, the percentage of animals affected and not affected by helminths of the total is the same and is $36 \%$.

\section{Discussion}

It has been experimentally established that of all the studied settlements it showed that in most cases $68.3 \%$ of helminthic diseases of dogs and cats run as mixed invasions, and a minority of cases $31.7 \%$ of cases run as mono invasions $[15,16]$. This factor must be taken into account when diagnosing and prescribing treatment to these animals and developing control and prevention measures. When analyzing the data in the table, it was found that dogs of different ages had different lesions of intestinal helminths. Puppies under 1 month of age were affected by Toxocara canis [17]. Other pathogens in puppies at this age could not be detected. This invasion was registered in dogs under 1 year of age. The pathogen Toxocara canis could not be detected in older individuals. Young animals aged 1 to 6 months were particularly susceptible to nematode infestation. They have a high degree of infestation with clinical manifestations of the disease: poor appetite or lack thereof, diarrhea, intermittent vomiting with the release of nematodes in some animals, etc. [18].

Several species of nematodes and cestodes in different associations were found in young dogs aged 4 months and older. According to the results, the average extent of invasion was $67.1 \%[19,20]$.

The level of extensiveness of the invasion is influenced by the use of dogs - hunting, protection, decorative purpose «room dogs», as well as stray animals.

Study limitations. The limitation of the research is the insufficient number of the studied settlements involved in the experiment, for a more accurate statistical calculation of the results obtained by region.

Prospects for further research. The prospect of further research is to expand the number of settlements and develop measures to control pathogens. 


\section{Conclusions}

It was established that among the analyzed cases of helminthic diseases in cities and suburban areas during 2018-2020, the following diseases were registered: toxocariasis of dogs, cestodes, uncinariosis of dogs. Among the blood-parasitic diseases were diagnosed with heartworm disease, babesiosis of dogs. Ectoparasitosis has been diagnosed with demodectic mange, otodectosis, canine and cat sarcoptosis, and carnivorous syphonepterosis.

It has been proven that helminthic diseases of dogs run as mixed invasion, and a minority of cases $31.7 \%$ of cases run as mono invasion. Of the total number of patients with helminthic diseases, $73.4 \%$ of the total number of animals were accompanied by other diseases of infectious and non-infectious ethology.

\section{Conflict of interests}

The authors declare there is no conflict of interests.

\section{Financing}

The research is part of the research work of the Department of Veterinary Examination, Microbiology, Zoohygiene and Safety and Quality of Livestock Products of Sumy NAU on «Forecasting the risks of transboundary entry and spread of particularly dangerous animal diseases and development of scientifically substantiated disinfection systems based on innovative imports» (No. state registration 0115U001342, 2018-2023)

\section{References}

[1] Raza, A., Rand, J., Qamar, A., Jabbar, A., Kopp, S. (2018). Gastrointestinal Parasites in Shelter Dogs: Occurrence, Pathology, Treatment and Risk to Shelter Workers. Animals, 8 (7), 108. doi: http://doi.org/10.3390/ani8070108

[2] Yong, T.-S., Lee, K.-J., Shin, M. H., Yu, H. S., Suvonkulov, U., Sergeevich, T. B. et. al. (2019). Prevalence of Intestinal Helminth Infections in Dogs and Two Species of Wild Animals from Samarkand Region of Uzbekistan. The Korean Journal of Parasitology, 57 (5), 549-552. doi: http://doi.org/10.3347/kjp.2019.57.5.549

[3] Nagayasu, E., Aung, M. P. P. T. H. H., Hortiwakul, T., Hino, A., Tanaka, T., Higashiarakawa, M. et. al. (2017). A possible origin population of pathogenic intestinal nematodes, Strongyloides stercoralis, unveiled by molecular phylogeny. Scientific Reports, 7 (1). doi: http://doi.org/10.1038/s41598-017-05049-x

[4] Eguía-Aguilar, P., Cruz-Reyes, A., Martínez-Maya, J. J. (2005). Ecological analysis and description of the intestinal helminths present in dogs in Mexico City. Veterinary Parasitology, 127 (2), 139-146. doi: http://doi.org/10.1016/j.vetpar.2004.10.004

[5] Sulieman, Y., Zakaria, M. A., Pengsakul, T. (2020). Prevalence of intestinal helminth parasites of stray dogs in Shendi area, Sudan. Annals of parasitology, 66 (1), 115-118.

[6] Lloyd, S. (2006). Seroprevalence of Toxocara canis in sheep in Wales. Veterinary Parasitology, 137 (3-4), $269-272$. doi: http://doi.org/10.1016/j.vetpar.2006.01.024

[7] Munro, R., Munro, H. M. C. (1978). Intestinal helminthiasis in dogs in fiji. Australian Veterinary Journal, 54 (1), $44-44$. doi: http://doi.org/10.1111/j.1751-0813.1978.tb00278.x

[8] Chidumayo, N. N. (2018). Epidemiology of canine gastrointestinal helminths in sub-Saharan Africa. Parasites Vectors, 11 (1). doi: http://doi.org/10.1186/s13071-018-2688-9

[9] Wangchuk, P., Lavers, O., Wishart, D. S., Loukas, A. (2020). Excretory/Secretory Metabolome of the Zoonotic Roundworm Parasite Toxocara canis. Biomolecules, 10 (8), 1157. doi: http://doi.org/10.3390/biom10081157

[10] Eslahi, A. V., Badri, M., Khorshidi, A., Majidiani, H., Hooshmand, E., Hosseini, H. et. al. (2020). Prevalence of Toxocara and Toxascaris infection among human and animals in Iran with meta-analysis approach. BMC Infectious Diseases, 20 (1). doi: http://doi.org/10.1186/s12879-020-4759-8

[11] Furtado, L. F. V., Dias, L. T. de O., Rodrigues, T. de O., Silva, V. J. da, Oliveira, V. N. G. M. de, Rabelo, É. M. L. (2020). Egg genotyping reveals the possibility of patent Ancylostoma caninum infection in human intestine. Scientific Reports, 10 (1). doi: http://doi.org/10.1038/s41598-020-59874-8

[12] Nonaka, N., Oka, M., Kamiya, M., Oku, Y. (2008). A latex agglutination test for the detection of Echinococcus multilocularis coproantigen in the definitive hosts. Veterinary Parasitology, 152 (3-4), 278-283. doi: http://doi.org/10.1016/ j.vetpar.2007.12.029

[13] Dovhii, Yu. Yu., Feshchenko, D. V., Bakhur, T. I. (2012) Porivnialna efektyvnist koproovoskopichnykh metodiv diahnostyky invaziinykh khvorob tvaryn. Visnyk ZhNAEU, 1 (3 (1)), 54-57. 
[14] Ponomar, S. I., Honcharenko, V. P., Soloviova, L. M. (2010). Dovidnyk z dyferentsiiuvannia zbudnykiv invaziinykh khvorob tvaryn. Kyiv: Ahrarna osvita, 327.

[15] Bisoffi, Z., Buonfrate, D., Montresor, A., Requena-Méndez, A., Muñoz, J., Krolewiecki, A. J. et. al. (2013). Strongyloides stercoralis: A Plea for Action. PLoS Neglected Tropical Diseases, 7 (5), e2214. doi: http://doi.org/10.1371/journal.pntd.0002214

[16] Jaleta, T. G., Zhou, S., Bemm, F. M., Schär, F., Khieu, V., Muth, S. et. al. (2017). Different but overlapping populations of Strongyloides stercoralis in dogs and humans - Dogs as a possible source for zoonotic strongyloidiasis. PLOS Neglected Tropical Diseases, 11 (8), e0005752. doi: http://doi.org/10.1371/journal.pntd.0005752

[17] Zheng, W.-B., Zou, Y., Elsheikha, H. M., Liu, G.-H., Hu, M.-H., Wang, S.-L., Zhu, X.-Q. (2019). Serum metabolomic alterations in Beagle dogs experimentally infected with Toxocara canis. Parasites \& Vectors, 12 (1). doi: http://doi.org/ 10.1186/s13071-019-3703-5

[18] Chen, J., Liu, Q., Liu, G.-H., Zheng, W.-B., Hong, S.-J., Sugiyama, H. et. al. (2018). Toxocariasis: a silent threat with a progressive public health impact. Infectious Diseases of Poverty, 7 (1). doi: http://doi.org/10.1186/s40249-018-0437-0

[19] Sperotto, R. L., Kremer, F. S., Aires Berne, M. E., Costa de Avila, L. F., da Silva Pinto, L., Monteiro, K. M. et. al. (2017). Proteomic analysis of Toxocara canis excretory and secretory (TES) proteins. Molecular and Biochemical Parasitology, 211, 39-47. doi: http://doi.org/10.1016/j.molbiopara.2016.09.002

[20] Zhu, X.-Q., Korhonen, P. K., Cai, H., Young, N. D., Nejsum, P., von Samson-Himmelstjerna, G. (2015). Genetic blueprint of the zoonotic pathogen Toxocara canis. Nature Communications, 6 (1). doi: http://doi.org/10.1038/ncomms7145

How to cite: Morozov, B., Berezovskyi, A. (2021). Monitoring of parasitic diseases of dogs. EUREKA: Health Sciences, 4, $109-116$. doi: http://doi.org/10.21303/2504-5679.2021.001987 